\title{
METODE HIDDEN MARKOV MODEL UNTUK PEMANTAUAN MASA SUBUR WANITA BERBASIS ANDROID
}

\author{
Irsandi Satria Wicaksana ${ }^{1}$, Sabar Setiawidayat ${ }^{2}$, Dedi Usman Effendy ${ }^{3}$ \\ ${ }^{123}$ Teknik Elektro Universitas Widyagama \\ irsandiwicaksana@gmail.com
}

\begin{abstract}
Abstrak
Hingga saat ini masa subur atau ovulasi pada wanita dapat di ketahui dengan metode servik, monitoring suhu basal, metode peak day dan metode standard day. Dalam penelitian ini dikembangkan metode saliva ferning, yaitu dengan mendeteksi melalui kristal air liur. Citra saliva ferning didapat melalui mikroskop digital dengan perbesaran 100 kali. Citra akan diklasifikasikan berdasarkan pola citra dengan pola acak, pola titik garis dan pola garis yang dominan. Berdasarkan perbedaan pola citra maka akan diklasifikasikan untuk menentukan masa tidak subur, masa transisi, dan masa subur yang sedang berlangsung. Nilai piksel dari citra akan diidentifikasi menggunakan metode hidden markov model dan ditampilkan pada smartphone android. Hasil penelitian menunjukkan nilai piksel, untuk masa tidak subur sebesar 8463 hingga 33302, masa transisi 39442 hingga 77315 dan masa subur diatas 77702, dengan akurasi identifikasi sebesar 95\%. Sampel saliva yang baik yaitu saliva yang tidak terkontaminasi, umumnya di pagi hari setelah bangun tidur.
\end{abstract}

Kata kunci: masa subur, kristal air liur, hidden markov model, android

\begin{abstract}
Until now, fertility or ovulation in women can be known by the cervical method, monitoring of basal temperature, peak day method and standard day method. In this study a method of salivary ferning was developed, namely by detecting it through saliva crystals. The image of ferning saliva is obtained through a digital microscope with a magnification of 100 times. The image will be classified based on the image pattern with random patterns, line point patterns and dominant line patterns. Based on differences in image patterns it will be clasification to determine the infertile period, the transition period, and the ongoing fertile period. The pixel value of the image will be identified using the hidden markov model and displayed on an android smartphone. The results showed pixel values, for infertile periods of 8463 to 33302, transition periods 39442 to 77315 and fertile periods above 77702, with identification accuracy of 95\%. Good sample saliva is uncontaminated saliva in the morning after waking up
\end{abstract}

Keywords: ovulasi, saliva ferning, hidden markov model, android

JASEE Journal of Application and Science on Electrical Engineering 26 


\section{PENDAHULUAN}

Ovulasi (Masa Subur) pada wanita adalah suatu masa dalam siklus menstruasi wanita. Siklus ini berlangsung antara 26-32 hari kalender, yang dimana pada hari ke 12 hingga hari ke 18 adalah masa tersubur dari wanita [1]. Masa subur dihitung sejak hari pertama haid terjadi. Penentuan masa subur ini masih terpaku pada perhitungan menurut kalender, namun perhitungan menurut kalender masih kurang akurat karena masa subur seseorang masih dipengaruhi oleh hormone seseorang itu sendiri [2], [3].

Penentuan masa subur dapat diketahui melalui beberapa metode monitoring. Penelitian yang dilakukan oleh Guermandi dkk menggunakan metode Luteinizing Hormone (LH) mengamati masa subur melalui urine yang diuji menggunakan $\mathrm{LH}$ strip test [4]. Pembacaan LH striptest ini sering salah karena pengujian yang tidak tepat dan memiliki biaya yang cukup mahal untuk setiap kali pengujian. Metode Standard Days menurut penelitian Lundgren dkk dengan menentukan masa subur pada satu siklus mestruasi pada hari ke-8 hingga hari ke-10 sebagai penanda masa puncak kesuburan wanita [5]. Metode ini sesuai dengan siklus menstruasi antara 26-32 hari, namun metode ini kurang efektif karena perubahan hormone dan gaya hidup membuat siklus berubah-ubah dengan akurasi hasil pembacaan 78\%. Menurut Porucznik dkk metode Peak Day adalah metode yang baru dalam monitor ovulasi [6]. Metode ini memandu wanita untuk mengidentifikasi masa subur dengan estimasi hasil ovulasi menggunakan kalender khusus. Kalender ini berfungsi untuk mengidentifikasi lendir servik dalam identifikasi hari masa subur.

Penelitian yang dilakukan oleh Eksdale dkk menyebutkan bahwa masa subur wanita dapat diketahui melalui perubahan bentuk saliva (air liur) yang dikeringkan untuk diamati [7]. Penelitian masa subur melalui saliva juga dilakukan oleh Riska dkk yang menyebutkan bahwa masa subur dapat diketahui dari perubahan saliva ferning pada setiap fasenya. Perubahan ini diakibatkan karena adanya peningkatan kadar hormone sistem seperti Hormone Estrogen dan Prostegeron. Kristal saliva yang mengering dapat dilihat melalui mikroskop [2].

Hidden markov model adalah salah satu metode yang sering digunakan untuk pencocokan citra. Salah satu penelitian yang dilakukan oleh Afita, mengklarifikasikan penyakit darah (leukimia) kedalam 3 klasifikasi dengan pengulangan 5 dan 10 kali mendapatkan akurasi sebesar 60\% sampai 82,76\% [8]. Penelitian yang dilakukan Sepritahara, pada sistem pengenalan wajah menggunakan metode hidden markov model mendapatkan akurasi 84,28\% dengan 70 database [9].

Pada penelitian ini mengusulkan pemeriksaan masa subur wanita menggunakan saliva ferning. Saliva akan ditempatkan pada sebuah preparat kaca dan dikeringkan untuk membentuk kristal pada sampel saliva tadi. Sampel saliva tadi akan diamati menggunakan mikroskop digital dan citra yang didapat akan di kirim menuju android untuk dihitung jumlah piksel citra tersebut. Metode yang digunakan adalah metode pencocokan Hidden Markov Model, yaitu sebuah metode yang digunakan untuk pengenalan citra. 


\subsection{Ovulasi (Masa Subur)}

\section{STUDI PUSTAKA}

Ovulasi atau dalam bahasa Indonesia Masa Subur pada wanita dewasa adalah suatu masa dalam siklus menstruasi wanita dimana terdapat sel telur yang matang yang siap dibuahi. Masa Subur wanita adalah suatu masa yang berada disekitar waktu keluarnya sel telur tersebut (umumnya bagi yang mempunyai siklus haid 28-30 hari berada antara hari ke 12 hingga hari ke 18 dihitung dari hari pertama haid) [10]. Untuk mengetahui masa subur terdapat beberapa metode antara lain, metode Lendir Servik, monitor Luteinizing Hormone Urine, monitor Basal Body Temperature, metode Peakday, metode Standard day dan metode Saliva [2], [5]. Masa transisi adalah masa yang terjadi sebelum dan sesudah masa subur berlangsung. Masa transisi pertama terjadi setelah menstruasi berlangsung, dan kembali terjadi keduakali sesudah masa subur berlangsung hingga masa menstruasi terjadi. Masa tidak subur adalah dimana seorang wanita akan mengalami masa menstruasi 5 hingga 7 hari.

Metode saliva belum banyak digunakan dan di aplikasikan langsung oleh wanita saat ini. Saliva yang diambil dari bawah lidah memiliki kepekaan terhadap perubahan hormone yang terjadi selama siklus menstruasi berlangsung.

\subsection{Saliva Ferning}

Saliva dalam bahasa Inggris adalah cairan bening yang dihasilkan dalam mulut manusia. Saliva dihasilkan dan dideskrenasikan oleh kelenjar ludah. Cairan ini mengandung 99\% air dan $1 \%$ bermacam-macam zat, seperti kalsium, fosfor, natrium, magnesium, dan lain-lain [2]. Pada saat masa subur, kadar hormone system reproduksi melonjak naik seperti hormone Estrogen dan Progesteron. Untuk mendeteksi peningkatan kadar hormone ini dapat dilakukan melalui pengamatan pada saliva [7]. Pada masa subur anatomi air liur mengalami perubahan yang dikenal dengan istilah Saliva Ferning. Istilah "Ferning" berkaitan dengan bentuk kristal air liur yang bila diamati dengan mikroskop berbentuk seperti tulang daun atau daun pakis.

\subsection{Mikroskop Digital}

Modul kamera mikroskop digunakan untuk melihat benda yang tak dapat dilihat langsung oleh mata biasa karena benda yang sangat kecil. Perbesaran yang dibutuhkan untuk melihat Kristal pada saliva adalah 100 kali perbesaran [11]. Dengan perbesaran ini objek dapat diamati secara detail. Pada modul kamera ini sudah dilengkapi dengan led untuk pencahayaan objek pengamatan. Intensitas cahaya dapat di atur sesuai kebutuhan pengamatan.

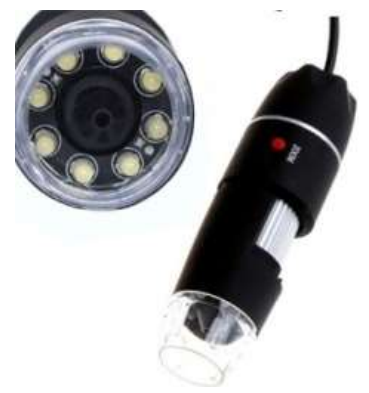

Gambar 1. Mikroskop Digital

JASEE Journal of Application and Science on Electrical Engineering 28

https://doi.org/10.31328/iasee.v1i01.7 


\subsection{Rasberry Pi 3}

Rasberry Pi 3 model B adalah keluarga Rasberry Pi model terbaru. Board mini computer memiliki dimensi yang sangat kecil yaitu $85.6 \mathrm{~mm} \times 56 \mathrm{~mm}$. terdapat 4 port USB, Ethernet port, 40 pin Extended GPIO, dan dilengkapi processor 64bit Boardcom BCM2837 Quadcore CPU $1.2 \mathrm{GHz}$, terdapat HDMI video output dan Micro SD card slot [12], [13].

\subsection{Android}

Android merupakan perangkat bergerak pada sistem operasi untuk telepon seluler berbasis Linux. Android juga menyediakan platform terbuka bagi pengembang untuk menciptakan suatu aplikasi sendiri yang mampu berjalan di atas piranti Android [14]. Sistem operasi android pertama kali diciptakan oleh pengembang Inc. tahun 2005, kemudian digunakan untuk komersial pada tahun 2008 setelah diambil alih oleh Google dan dikembangkan dengan versi 1.5 Cupcake, android terus mengalami perkembangan hingga saat ini. Versi android yang pernah beredar antara lain : 1.5 Cupcake, 1.6 Donut, 2.1 Esclair, 2.2 Froyo, 2.3 Gingerbread, 3.0 Honeycomb, 4.0 Ice Cream Sandwich, 4.1 Jelly Bean, 4.4 Kitkat, 5.0 Lollipop, 6.0 Marshmallow dan 7.0 Nougat.

\subsection{Image Processing}

Image processing atau pengolahan citra adalah proses untuk mengamati dan menganalisa suatu objek tanpa berhubungan langsung dengan objek yang diamati. Proses dan analisanya melibatkan persepsi visual dengan data masukan maupun data keluaran yang diperoleh berupa citra dari objek yang diamati [16]. Terdapat dua bagian pada proses pembentukan citra, yaitu geometri citra yang menentukan suatu titik dalam pemandangan diproyeksikan pada bidang citra dan fisik cahaya yang menentukan kecerahan suatu titik pada bidang citra sebagai fungsi pencahayaan pemandangan serta sifat-sifat permukaan.

Citra merupakan sekumpulan titik-titik dari gambar yang berisi informasi warna dan tidak tergantung pada waktu. Umumnya citra dibentuk dari kotakkotak persegi empat yang teratur sehingga jarak horizontal dan vertikal antar piksel sama pada seluruh bagian citra. Dalam pengambilan citra hanya citra digital yang dapat diproses oleh komputer digital, data citra yang dimasukkan berupa nilai-nilai integer yang menunjukkan nilai intensitas cahaya atau tingkat keabuan setiap piksel.

Citra $\mathrm{f}(\mathrm{x}, \mathrm{y})$ disimpan dalam memori komputer atau penyimpan bingkai citra dalam bentuk array $\mathrm{n} \times \mathrm{m}$ dari contoh diskrit dengan jarak sama, sebagai berikut :

$$
f(x, y)=\left[\begin{array}{cccc}
f(0,0) & f(0,1) & \cdots & f(0, m-1) \\
f(1,0) & f(1,1) & \cdots & f(1, m-1) \\
\cdots & \cdots & \cdots & \cdots \\
f(n, 0) & f(n 1) & \cdots & f(n, m-1)
\end{array}\right]
$$

Setiap elemen dari array di atas disebut sebagai piksel yang merupakan suatu daerah bujur sangkar kecil dengan ukuran tertentu dan menunjukkan harga intensitas keabuan piksel pada lokasi yang bersangkutan. Ukuran piksel ini sering disebut resolusi piksel. 


\subsection{Hidden Markov Model (HMM)}

Hidden Markov Model merupakan pemodelan probabilitas suatu sistem dengan mencari parameter-parameter yang tidak diketahui untuk mempermudah proses analisis sistem tersebut [17]. Untuk membentuk HMM, pertama tentukan hidden state-nya $\mathrm{S}=\{\mathrm{S} 1, \mathrm{~S} 2, \ldots \mathrm{SN}\}$, dimana $\mathrm{N}$ adalah jumlah hidden state [18]. Pada penelitian ini jumlah hidden state-nya adalah 3 dengan pertimbangan jumlah masa dalam siklus menstruasi, usia dan menstruasi terakhir. Kemudian alokasikan probabilitas transisi antar state (matriks transisi),

$$
\begin{aligned}
& A=\{\text { aij }\}, \text { untuk } 1 \leq i, j \leq N \\
& \text { aij }=P\left[q t+1=\frac{S j}{q t}=S i\right]
\end{aligned}
$$
di state $i$.

yaitu peluang berada di state $\mathrm{j}$ pada waktu $\mathrm{t}+1$ jika pada waktu $\mathrm{t}$ berada

Input untuk membangun HMM yaitu Citra yang telah ditransformasi menjadi barisan vektor ciri, $\mathrm{O}=\{\mathrm{O} 1, \mathrm{O} 2, \ldots, \mathrm{OM}\}$, dimana $\mathrm{M}$ adalah panjang observasi, ke peluang kemunculannya pada suatu barisan hidden satete tertentu. Untuk probabilitas kemunculan perubah yang terobservasi pada suatu state (matrik emisi) dinotasikan dengan

$$
\begin{aligned}
& B=\{B j(k)\}, 1 \leq j \leq N, 1 \leq k \leq M \\
& b j(k)=P\left[O_{k} \text { terhadap } t \mid q_{t}=S_{j}\right], 0 \leq b j(k) \text { dan } \sum_{k-1}^{M} b j(k)
\end{aligned}
$$

Matriks distribusi probabilitas pada tahap awal berada di state i dinotasikan dengan

$$
\begin{aligned}
& \pi=\left\{\pi_{i}\right\}, \text { untuk } 1 \leq j \leq N \\
& \pi_{i}=P\left[q_{1} S_{i}\right], 0 \leq \pi_{i} \text { dan } \sum_{i=1}^{N} \pi_{i}=1
\end{aligned}
$$

Dengan menggunakan notasi-notasi tersebut, maka suatu HMM dapat dilambangkan dengan

$$
\lambda=(A, B, \pi
$$

\section{METODOLOGI}

Tahapan yang dilakukan pada penelitian ini adalah sebagai berikut :

1. Studi literature

2. Pengumpulan data

3. Rekayasa kebutuhan

4. Perancangan dan Implementasi

5. Pengujian

6. Penarikan kesimpulan 


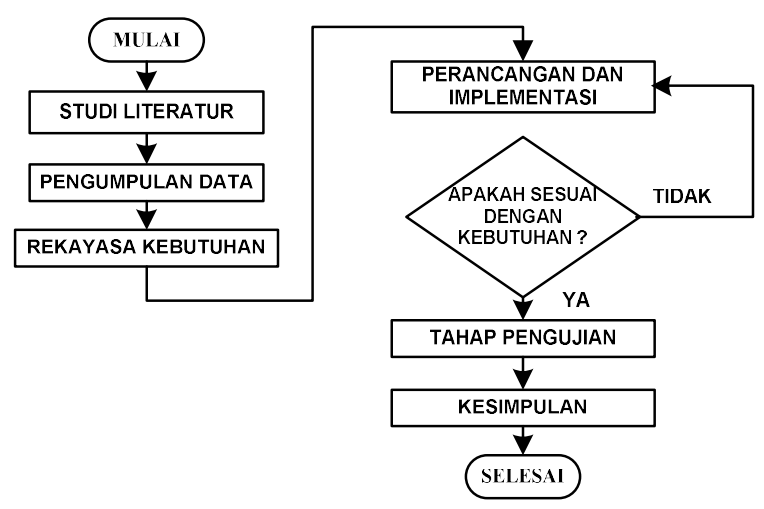

Gambar 2. Tahapan Penelitian

\subsection{Studi Literatur}

Pada tahapan ini dilakukan pengumpulan literature yang berkaitan dengan cara penentuan masa subur, masa peralihan dan masa tidak subur, siklus menstruasi, rasberrypi3, android, image processing dan metode hidden markov model. Setelah literature terkumpul akan dipelajari untuk disiapkan bahan dasar penelitian ini.

\subsection{Pengumpulan Data}

Data yang digunakan dalam penelitian ini adalah data citra saliva yang telah dikeringkan (ferning saliva) dan ph dari air liur. Citra saliva yang diambil dari satu siklus penuh masa menstruasi yang meliputi masa tidak subur, masa transisi dan masa subur. Citra diambil dari beberapa tahapan yaitu pagi hari sebelum melakukan aktifitas apapun, siang hari setelah mengkonsumsi teh, dan malam hari setelah mengkonsumsi makanan. Data citra diambil menggunakan mikroskop digital dengan kemampuan perbesaran 50-100 kali. Data diambil dari 10 orang wanita dengan rentang usia 18 sampai dengan 35 tahun, dengan jumlah data citra yang didapat sebanyak 90 data sampel dengan 30 gambar disetiap fasenya. Dari data tersebut sebanyak 33\% (30) sebagai data latih dan 67\% (60) sebagai data uji. Data diberi label sesuai dengan siklus yang berlangsung. Contoh data hasil pengambilan citra saliva ferning ditunjukkan pada gambar 3.

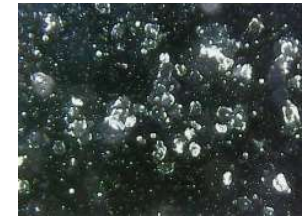

(a)

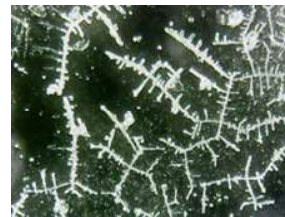

(b)

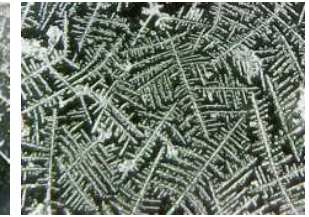

(c)

Gambar 3. Data Saliva Ferning

Gambar 3 merupakan citra pola dari saliva ferning ketika dikeringkan dalam waktu 5 - 15 menit. Pada gambar 3(a) merupakan masa tidak subur, 3(b) adalah masa transisi ke masa subur, dan 3(c) adalah masa subur dengan ciri munculnya pola daun pakis (ferning). Pola ini akan muncul pada tiga hari sampai empat hari sebelum masa subur dan sehari hingga dua hari setelah masa subur berakhir. 


\subsection{Rekayassa Kebutuhan}

Rekayasa kebutuhan merupakan salah satu cara dalam mempersiapkan penelitian. Tujuan dari analisis kebutuhan ini adalah untuk mengetahui perangkat keras dan perangkat lunak yang dibutuhkan untuk penelitian ini. Adapun kebutuhan yang wajib dipenuhi pada penelitian ini adalah kebutuhan perangkat keras seperti labtop atau pc.
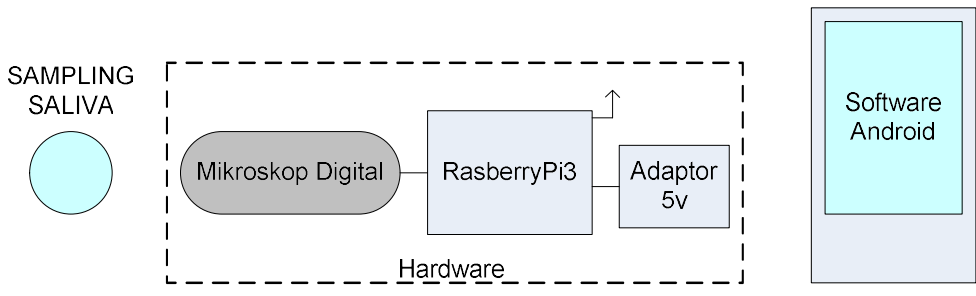

Gambar 4. Gambar Umum Sistem

Terdapat dua entitas utama dalam sistem yang akan dibangun yaitu hardware dan software. Hardware adalah alat yang akan digunakan oleh pengguna untuk menangkap citra sampel saliva yang telah didapat sebelumnya. Hardware ini tersusun dari komponen modul mikroskop digital untuk menangkap gambar sampel saliva dan rasberry pi 3 untuk menyimpan sementara hasil gambar yang didapat dan mengirimkannya kepada pengguna, dengan membuka tampilan software. Software ini adalah antarmuka penampil yang didapatkan dari pemrosesan hardware. Pada software ini, gambar sampling akan diolah untuk dan ditampilkan hasil pengujian.

\subsection{Perancangan dan Implementasi}

Perancangan dan implementasi ini meliputi perancangan perangkat keras (hardware) dan perancangan perangkat lunak (software). Perangkat keras disusun dari modul mikroskop, raspberry pi 3 dan adaptor untuk sumber energi. Sedangkan untuk perangkat lunak digunakan untuk penampil hasil tangkapan gambar yang didapatkan. Pada perangkat lunak dibubuhkan metode pengenalan citra dan pengolahan citra.
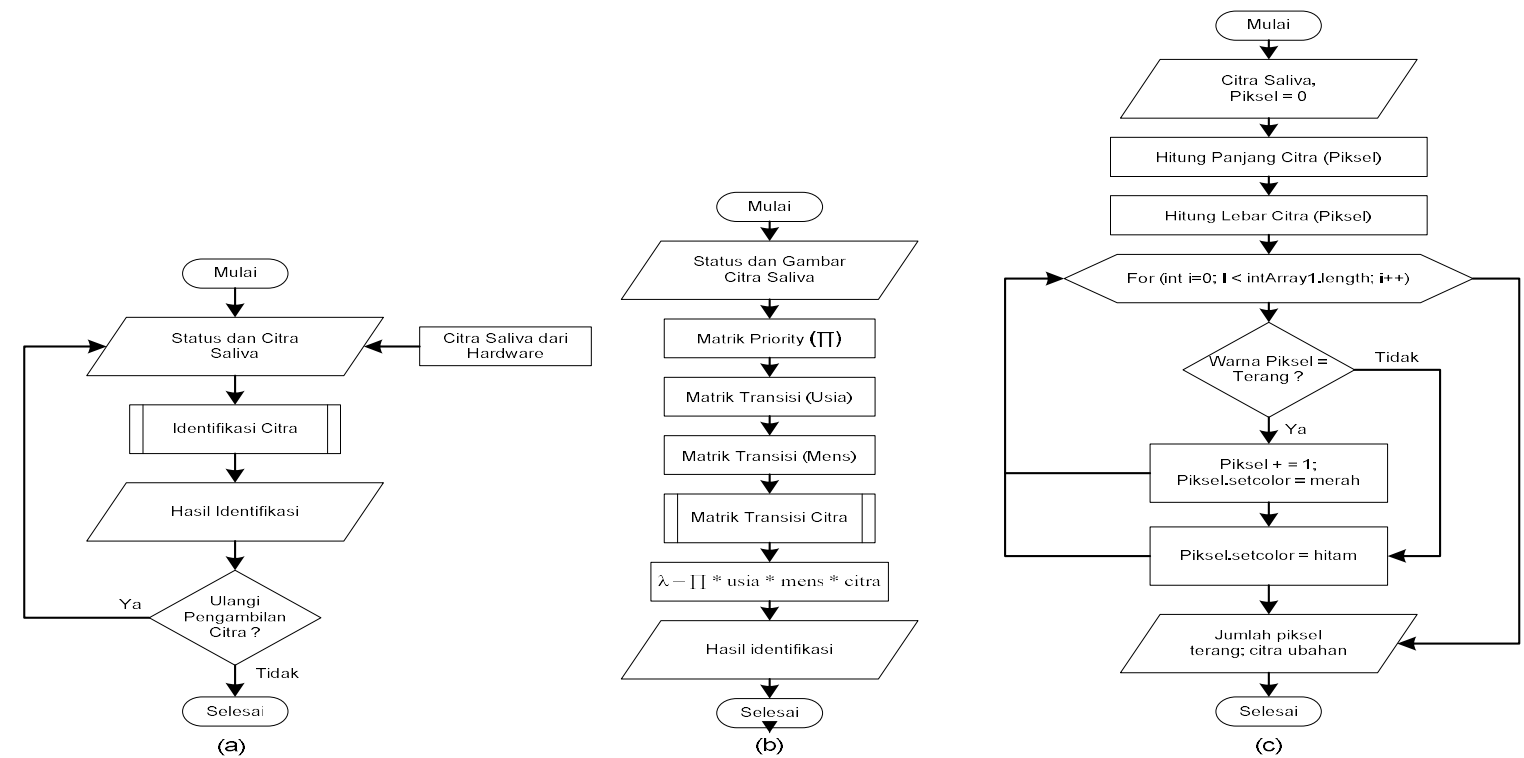

Gambar 5. Diagram Alir Kerja Sistem (a), Pemrosesan Citra (b) dan Pengolahan Citra (c) JASEE Journal of Application and Science on Electrical Engineering 


\subsection{Pengujian}

Metode hidden markov model sebagai pengenalan citra pada saliva ferning mendapatkan pelatihan yang sepenuhnya diatur oleh aplikasi yang dibuat. Pengujian ini dengan membandingkan hasil tangkapan citra yang diolah menggunakan aplikasi yang dibangun dengan metode lain untuk mengetahui hasil yang akurat. Perbandingan dengan metode billings dan metode LH strip test. Citra saliva juga di uji waktu pengambilannya untuk mendapatkan waktu yang tepat untuk mendapatkan hasil yang maksimal. Pengujian juga dilakukan pada pengukuran ph saliva ini dilakukan untuk mengetahui pengaruh ph pada citra saliva ferning yang didapat.

\section{HASIL DAN PEMBAHASAN}

\subsection{Pengolahan Citra}

Citra saliva ferning akan di hitung dan dirubah bentuknya kedalam piksel. Warna putih akan dijadikan merah sedangkan warna keabuan dan hitam akan dijadikan warna hitam. warna merah memiliki kecerahan yang tinggi sedangkan warna hitam akan dinilai dengan 0. Pengolahan citra juga dilakukan untuk menghilangkan noise pada citra sampling.

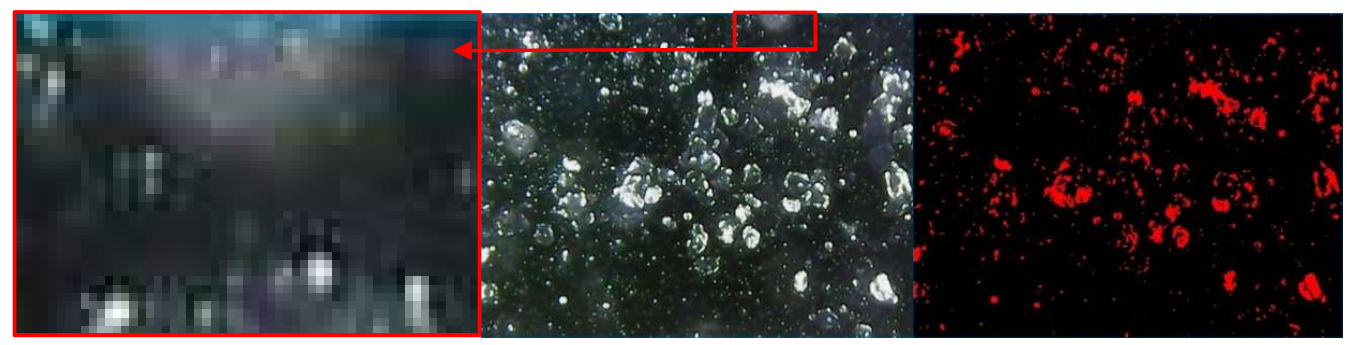

Gambar 6. Contoh Noise dan Perubahan Warna pada Citra

Tabel 1. Perubahan Bentuk Citra Dalam Piksel

\begin{tabular}{|c|c|c|c|}
\hline No & Tidak Subur & Peralihan & Subur \\
\hline 1 & 21055 & 50507 & 127700 \\
\hline 2 & 15971 & 51057 & 96863 \\
\hline 3 & 33105 & 74850 & 82322 \\
\hline 4 & 28751 & 45794 & 77702 \\
\hline 5 & 18706 & 39442 & 103571 \\
\hline 6 & 27925 & 67806 & 83688 \\
\hline 7 & 15781 & 50520 & 100906 \\
\hline 8 & 8463 & 51074 & 103959 \\
\hline 9 & 33302 & 48690 & 112063 \\
\hline 10 & 14206 & 77315 & 87512 \\
\hline Nilai Max & 33302 & 77315 & 127700 \\
\hline Nilai Min & 8463 & 39442 & 77702 \\
\hline
\end{tabular}

Nilai piksel yang didapat dari 10 citra setiap masa siklus. Masa tidak subur memiliki rentang nilai 8463 hingga 77315 piksel, masa peralihan memiliki rentang 39442 hingga 77315 piksel, dan masa subur diatas 77702 piksel. 


\subsection{Manualisasi Data}

Manualisasi data dilakukan untuk mengetahui perhitungan manual dari sistem yang dibuat dan pembuatan aturan sesuai dengan metode yang diterapkan.

Tabel 2. Aturan Saliva Ferning [18]

\begin{tabular}{|c|c|c|c|c|}
\hline Aturan & Jumlah Piksel & Peluang Tidak Subur & Peluang Peralihan & Peluang Subur \\
\hline 1 & $\leq 33302$ & 0.9 & 0.5 & 0.2 \\
\hline 2 & $\geq 33303-\leq 77316$ & 0.6 & 0.9 & 0.6 \\
\hline 3 & $>77316$ & 0.2 & 0.5 & 0.9 \\
\hline
\end{tabular}

Tabel 3. Aturan Usia [18]

\begin{tabular}{|c|c|c|c|c|}
\hline Aturan & Usia & Peluang Tidak Subur & Peluang Peralihan & Peluang Subur \\
\hline 1 & $<18$ & 0.9 & 0.8 & 0.8 \\
\hline 2 & $<35$ & 0.8 & 0.8 & 0.8 \\
\hline 3 & $>36$ & 0.9 & 0.9 & 0.8 \\
\hline
\end{tabular}

Tabel 4. Menstruasi Terakhir [18]

\begin{tabular}{|c|c|c|c|c|}
\hline Aturan & Mens Terakhir & Peluang Tidak Subur & Peluang Peralihan & Peluang Subur \\
\hline 1 & $\leq 3$ hari & 0.9 & 0.7 & 0.7 \\
\hline 2 & > 3 hari & 0.8 & 0.8 & 0.8 \\
\hline
\end{tabular}

Perhitungan dari data yang didapat jika piksel yang diperoleh sebesar 17291, dengan usia penguji 27 tahun dan telah selesai masa menstruasi 20 hari yang lalu maka perhitungannya adalah [18]:

1. Hitung Peluang Setiap Masa Siklus

$=$ Aturan $3 \times$ Aturan $2 \times$ Aturan 3

Peluang Tidak Subur $\quad=0.9 \times 0.8 \times 0.8=0.576$

Peluang Peralihan $\quad=0.5 \times 0.8 \times 0.8=0.32$

Peluang Tidak Subur $\quad=0.2 \times 0.8 \times 0.8=0.128$

2. Persentase Hasil Setiap Masa Siklus

$\%$ Tidak Subur $=\frac{\text { Peluang Tidak Subur }}{(\text { Peluang Tidak Subur }+ \text { Peralihan }+ \text { Subu })} \times 100 \%$

$$
=\frac{0.576}{(0.576+0.32+0.128)} \times 100 \%=56.25 \%
$$

$\%$ Peralihan $=\frac{\text { Peluang Peralihan }}{(\text { Peluang Tidak Subur }+ \text { Peralihan }+ \text { Subur })} \times 100 \%$

$$
=\frac{0.32}{(0.576+0.32+0.128)} \times 100 \%=31.25 \%
$$

$\%$ Subur

$$
\begin{aligned}
& =\frac{\text { Peluang Subur }}{(\text { Peluang Tidak Subur }+ \text { Peralihan }+ \text { Subu })} \times 100 \% \\
& =\frac{0.576}{(0.432+0.504+0.336)} \times 100 \%=12.5 \%
\end{aligned}
$$


| Vol. 1 | No. 1 | Halaman 26 - 39

\subsection{Tampilan Aplikasi}

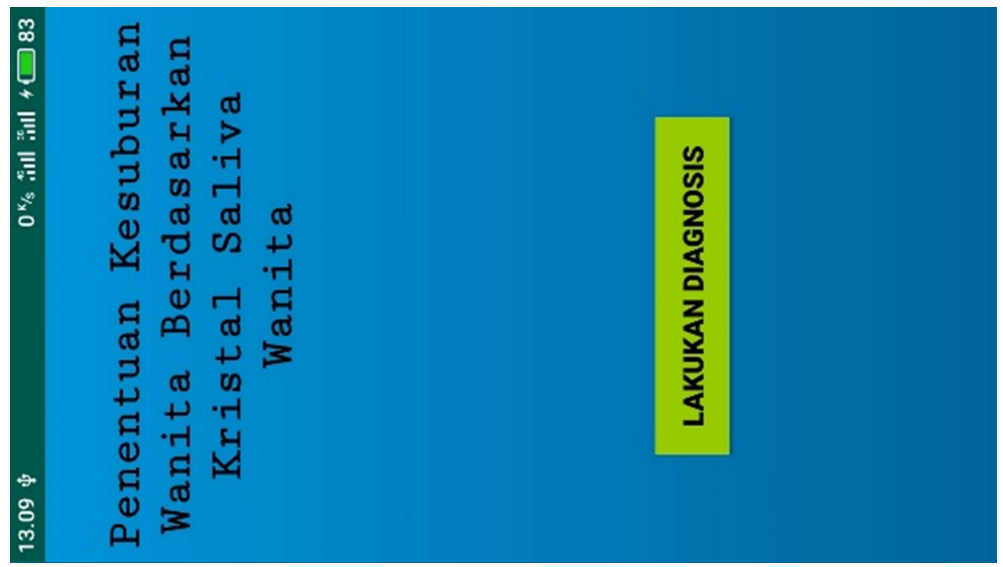

(a)

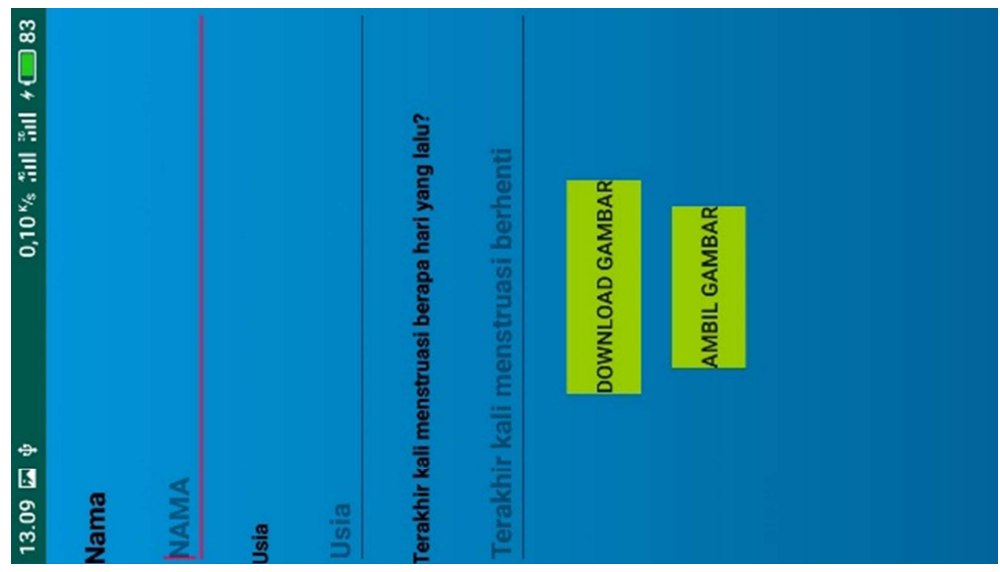

(b)

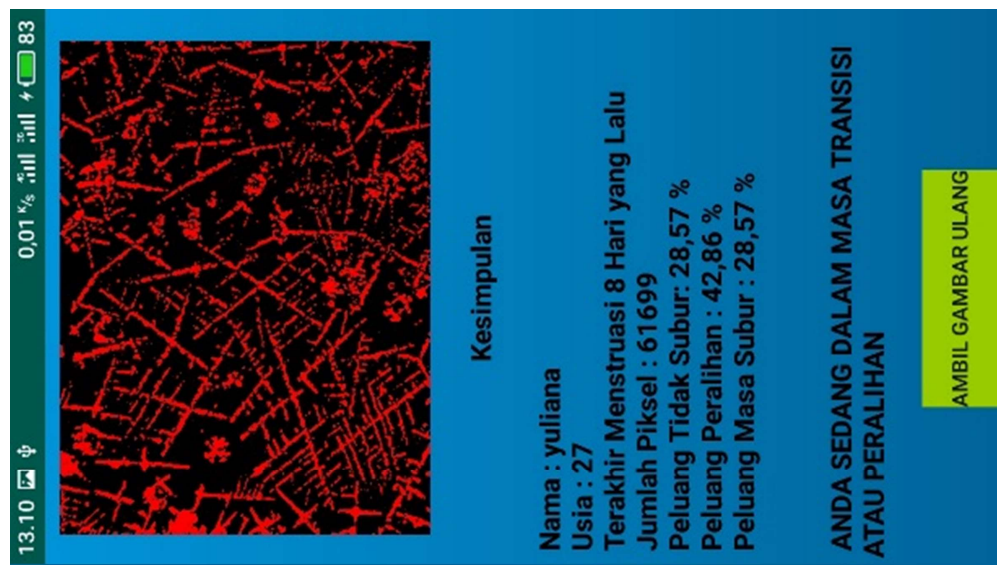

(c)

Gambar 7. Tampilan Aplikasi Pada Android

Gambar 7(a) adalah tampilan awal aplikasi, gambar 7 (b) adalah menu utama aplikasi, dimana pengguna mengisi nama, usia dan hari terakhir menstruasi. Terdapat dua tombol untuk mendonload citra dari hardware untuk disimpan pada memori smartphone android dan tombol kedua untuk memilih citra dari data penyimpanan. Gambar 7 (c) adalah tampilan hasil aplikasi setelah melakukan analisa citra. 


\subsection{Pengujian Pengenalan Data}

Pengujian dilakukan pada 60 sampel citra saliva dengan klasifikasi setiap siklus sebanyak 20 sampel citra. Hasil pengujian sampel saliva pada tabel 5 .

Tabel 5. Perbandingan Pengujian Sampel Setiap Kondisi

\begin{tabular}{|c|c|c|c|c|c|c|}
\hline No & Citra & $\begin{array}{c}\text { Hasil Pengenalan } \\
\text { Citra } \\
\end{array}$ & Citra & $\begin{array}{c}\text { Hasil Pengenalan } \\
\text { Citra } \\
\end{array}$ & Citra & $\begin{array}{c}\text { Hasil Pengenalan } \\
\text { Citra } \\
\end{array}$ \\
\hline 1 & Tidak Subur & Tidak Subur & Transisi & Transisi & Subur & Subur \\
\hline 2 & Tidak Subur & Tidak Subur & Transisi & Transisi & Subur & Subur \\
\hline 3 & Tidak Subur & Subur & Transisi & Transisi & Subur & Subur \\
\hline 4 & Tidak Subur & Tidak Subur & Transisi & Transisi & Subur & Subur \\
\hline 5 & Tidak Subur & Tidak Subur & Transisi & Transisi & Subur & Subur \\
\hline 6 & Tidak Subur & Tidak Subur & Transisi & Transisi & Subur & Subur \\
\hline 7 & Tidak Subur & Tidak Subur & Transisi & Transisi & Subur & Subur \\
\hline 8 & Tidak Subur & Tidak Subur & Transisi & Transisi & Subur & Subur \\
\hline 9 & Tidak Subur & Subur & Transisi & Transisi & Subur & Subur \\
\hline 10 & Tidak Subur & Tidak Subur & Transisi & Transisi & Subur & Subur \\
\hline 11 & Tidak Subur & Tidak Subur & Transisi & Transisi & Subur & Subur \\
\hline 12 & Tidak Subur & Tidak Subur & Transisi & Transisi & Subur & Subur \\
\hline 13 & Tidak Subur & Tidak Subur & Transisi & Transisi & Subur & Subur \\
\hline 14 & Tidak Subur & Tidak Subur & Transisi & Transisi & Subur & Subur \\
\hline 15 & Tidak Subur & Tidak Subur & Transisi & Transisi & Subur & Subur \\
\hline 16 & Tidak Subur & Tidak Subur & Transisi & Transisi & Subur & Subur \\
\hline 17 & Tidak Subur & Tidak Subur & Transisi & Transisi & Subur & Subur \\
\hline 18 & Tidak Subur & Tidak Subur & Transisi & Subur & Subur & Subur \\
\hline 19 & Tidak Subur & Tidak Subur & Transisi & Transisi & Subur & Subur \\
\hline 20 & Tidak Subur & Tidak Subur & Transisi & Transisi & Subur & Subur \\
\hline \multicolumn{2}{|c|}{ Hasil Benar } & 18 & Hasil Benar & 19 & Hasil Benar & 20 \\
\hline \multicolumn{2}{|r|}{ Hasil Salah } & 2 & Hasil Salah & 1 & Hasil Salah & 0 \\
\hline
\end{tabular}

Dari data yang didapat pada pengujian tabel1 tingkat akurasi pembacaan setiap masa siklus sebesar 90\% -100\%. Dengan total akurasi sebesar 95\% untuk seluruh siklus.

$$
\text { Akurasi }=\frac{\text { Hasil Benar }}{\text { Total sampel }} \times 100 \%=\frac{(18+19+20)}{60} \times 100 \%=95 \%
$$

\subsection{Perbandingan Pembacaan Data}

Data yang didapat juga dibandingkan dengan metode LH [19] dan Metode Bilings [20]. Pada metode LH hasil didapatkan antara Positive dan Negative. Metode Bilings hasil ditunjukkan dengan warna hijau untuk masa subur, warna kuning untuk masa transisi dan warna merah untuk masa tidak subur. Dari hasil pengamatan dan pengujian, metode saliva ferning mempunyai kesamaan hasil dengan metode lain yang dibandingkan dengan uji komparasi, untuk waktu pengambilan sampel yang baik ada pada pagi hari karena sampel belum terkontaminasi zat lain yang masuk ke dalam mulut. PH yang berubah tidak mempengaruhi sampel yang di uji. Hasil perbandingan pembacaan data pada tabel 6, tabel 7, tabel 8 . 
Tabel 6. Perbandingan Uji Pembacaan

\begin{tabular}{|c|c|c|c|c|}
\hline Tanggal & $\begin{array}{l}\text { Nama / } \\
\text { Umur }\end{array}$ & Hari ke- & Hasil LH & $\begin{array}{c}\text { Hasil Tangkapan } \\
\text { Gambar }\end{array}$ \\
\hline 4-Dec & \multirow{5}{*}{$\begin{array}{l}\text { Yuliana / } \\
27 \text { tahun }\end{array}$} & 1 & Negative & Tidak Subur \\
\hline 9-Dec & & 6 & Negative & Transisi \\
\hline 13-Dec & & 10 & Positive & Subur \\
\hline 20-Dec & & 17 & Negative & Subur \\
\hline 24-Dec & & 21 & Negative & Tidak Subur \\
\hline 4-Dec & \multirow{5}{*}{$\begin{array}{l}\text { Airin / } 23 \\
\text { tahun }\end{array}$} & 16 & Positive & Subur \\
\hline 5-Dec & & 17 & Negative & Subur \\
\hline 16-Dec & & 29 & Negative & Transisi \\
\hline 18-Dec & & 30 & Negative & Tidak Subur \\
\hline 20-Dec & & 2 & Negative & Tidak Subur \\
\hline 4-Dec & \multirow{5}{*}{$\begin{array}{l}\text { Indri / } 35 \\
\text { tahun }\end{array}$} & 16 & Positive & Subur \\
\hline 5-Dec & & 17 & Negative & Subur \\
\hline 16-Dec & & 28 & Negative & Tidak Subur \\
\hline 18-Dec & & 1 & Negative & Tidak Subur \\
\hline 24-Dec & & 7 & Negative & Transisi \\
\hline
\end{tabular}

Tabel 7. Perbandingan Waktu Pengambilan Sampel

\begin{tabular}{|c|c|c|c|c|}
\hline Tanggal & $\begin{array}{c}\text { Nama / } \\
\text { Umur }\end{array}$ & Pagi & Siang & Malam \\
\hline 4-Dec & \multirow{3}{*}{$\begin{array}{l}\text { Yuliana / } \\
27 \text { tahun }\end{array}$} & Tidak Subur & Tidak Subur & Subur \\
\hline 9-Dec & & Transisi & Subur & Transisi \\
\hline 14-Dec & & Subur & Subur & Subur \\
\hline 4-Dec & \multirow{3}{*}{$\begin{array}{c}\text { Airin / } \\
23 \text { tahun }\end{array}$} & Subur & Subur & Subur \\
\hline 16-Dec & & Transisi & Transisi & Subur \\
\hline 20-Dec & & Tidak Subur & Subur & Subur \\
\hline 4-Dec & \multirow{3}{*}{$\begin{array}{c}\text { Indri / } \\
35 \text { tahun }\end{array}$} & Subur & Subur & Subur \\
\hline 5-Dec & & Transisi & Transisi & Subur \\
\hline 18-Dec & & Tidak Subur & Tidak Subur & Subur \\
\hline
\end{tabular}

Tabel 8. Perbandingan $\mathrm{PH}$

\begin{tabular}{|c|c|c|c|c|}
\hline \multirow{2}{*}{ Tanggal } & \multirow{2}{*}{$\begin{array}{c}\text { Nama / } \\
\text { Umur }\end{array}$} & $\begin{array}{c}\text { Belum } \\
\text { Makan } \\
\text { dan } \\
\text { Minum }\end{array}$ & $\begin{array}{c}\text { Setelah } \\
\text { Minum } \\
\text { Teh }\end{array}$ & $\begin{array}{c}\text { Setelah } \\
\text { Makan }\end{array}$ \\
\cline { 1 - 3 } 4-Dec & \multirow{2}{*}{$\begin{array}{c}\text { Yuliana } \\
\text { /27 }\end{array}$} & 7 & 6 & 6 \\
\cline { 1 - 1 } tahun & 6 & 4 & 6 \\
\cline { 1 - 1 } 9-Dec & \multirow{2}{*}{$\begin{array}{c}\text { Airin } \\
\text { 14-Dec }\end{array}$} & 7 & 6 & 7 \\
\cline { 1 - 1 } tahun & 7 & 7 & 6 & 6 \\
\cline { 1 - 1 } 4-Dec & & 6 & 6 \\
\hline 16-Dec & & & & 6 \\
\hline 20-Dec & & &
\end{tabular}

\begin{tabular}{|c|c|c|c|c|}
\hline Tanggal & \multirow{2}{*}{$\begin{array}{c}\text { Nama / } \\
\text { Umur }\end{array}$} & $\begin{array}{c}\text { Belum } \\
\text { Makan } \\
\text { dan } \\
\text { Minum }\end{array}$ & $\begin{array}{c}\text { Setelah } \\
\text { Minum } \\
\text { Teh }\end{array}$ & $\begin{array}{c}\text { Setelah } \\
\text { Makan }\end{array}$ \\
\cline { 1 - 3 } 4-Dec & \multirow{2}{*}{$\begin{array}{c}\text { Indri } \\
\text { / 35 }\end{array}$} & 7 & 6 & 6 \\
\cline { 1 - 1 } tahun & 6 & 6 & 6 \\
\cline { 1 - 1 } 5-Dec & 7 & 5 & 6 \\
\hline
\end{tabular}

Hasil pada tabel 6 perbandingan pembacaan 3 metode didapatkan hasil yang berimbang, selisih pembacaan diakibatkan karena metode saliva mengidentifikasi melalui perubahan hormone yang terjadi saat itu. Pada tabel 7 
pembacaan sampel pada siang dan malam, hasil menunjukkan subur karena sampel yang didapat sudah terkontaminasi kegiatan narasumber, citra yang diperoleh titik merah dominan diseluruh citra. Pada tabel 8 pengujian ph yang didapat berbeda beda setiap waktunya, namun pada hasil ph pagi hari tidak mempengaruhi citra saliva yang didapatkan.

\section{KESIMPULAN}

Berdasarkan hasil penelitian yang telah dilakukan dapat disimpulkan bahwa masa subur (ovulasi) dapat dideteksi dan diklasifikasikan berdasarkan sampel citra saliva ferning. Metode Hidden Markov Model (HMM) berhasil melakukan pengenalan citra saliva ferning untuk menentukan siklus masa subur sebesar 95\%, dengan klasifikasi masa tidak subur sebesar 90\%, masa transisi sebesar 95\% dan masa subur sebesar 100\%. Sampel saliva yang terbaik adalah diwaktu pagi hari setelah bangun dari tidur, karena saliva yang di uji belum terkontaminasi zat lain yang masuk kedalam mulut. PH yang berubah tidak mempengaruhi sampel saliva yang di ujikan, namun kontaminasi dan kegiatan keseharian yang menggunakan mulut menyebabkan pembacaan sampel saliva kurang akurat.

Saran yang dapat diberikan berdasarkan uji coba dan evaluasi yang telah dilakukan adalah perubahan pada tampilan aplikasi agar lebih menarik lagi, menggunakan hardware yang lebih ringkas untuk memudahkan penggunaannya, kombinasi pengenalan pola citra untuk meningkatkan akurasi pengenalan citra.

\section{Daftar Rujukan}

[1] C. F. P. Sari, "Gambaran Lama Menstruasi Pada Remaja," Univ. Muhammadiyah Surak., Hlm. 19, 2018.

[2] R. M. Ersyari, R. Wihardja, Dan M. Dardjan, "Determination Of Ovulation In Women Using Saliva Ferning Test," Padjadjaran J. Dent., Vol. 26, No. 3, 2014.

[3] U. J. Shobrina, "Analisis Kinerja Pengiriman Data Modul Transceiver Nrf24101, Xbee Dan Wifi Esp8266 Pada Wireless Sensor Network," Phd Thesis, Universitas Brawijaya, 2017.

[4] E. Guermandi, W. Vegetti, M. M. Bianchi, A. Uglietti, G. Ragni, Dan P. Crosignani, "Reliability Of Ovulation Tests In Infertile Women," Obstet. Gynecol., Vol. 97, No. 1, Hlm. 92-96, 2001.

[5] I. Parmawati, "Merencanakan Atau Mencegah Kehamilan Secara Efektif Dan Efisien Dengan Monitor Ovulasi?: Studi Literatur," 2015.

[6] C. A. Porucznik, K. J. Cox, K. C. Schliep, Dan J. B. Stanford, "Pilot Test And Validation Of The Peak Day Method Of Prospective Determination Of Ovulation Against A Handheld Urine Hormone Monitor," Bmc Womens Health, Vol. 14, No. 1, Hlm. 4, 2014.

[7] J. Eskdale Dkk., "Interleukin-10 Microsatellite Polymorphisms And Il-10 Locus Alleles In Rheumatoid Arthritis Susceptibility," The Lancet, Vol. 352, No. 9136, Hlm. 1282-1283, 1998.

[8] A. P. Lestari, "Program Studi Teknik Elektro Departemen Teknik Elektro Fakultas Teknik Universitas Indonesia Genap 2007/2008," Hlm. 69, 2008.

[9] Sepritahara, "Sistem Pengenalan Wajah (Face Recognition) Menggunakan Metode Hidden Markov Model (Hmm)," Hlm. 81, 2012.

[10] W. Haryani, I. Siregar, Dan L. A. Ratnaningtyas, "Jurnal Riset Kesehatan," Poltekes Semarang, Hlm. 4, 2016. 
[11] S. Hartati, A. Harjoko, Dan T. W. Supardi, "The Digital Microscope And Its Image Processing Utility," Telkomnika Telecommun. Comput. Electron. Control, Vol. 9, No. 3, Hlm. 565, Des 2011.

[12] D. Prihatmoko, "Pemanfaatan Raspberry Pi Sebagai Server Web Untuk Penjadwalan Kontrol Lampu Jarak Jauh,” J. Infotel, Vol. 9, No. 1, Hlm. 84, Feb 2017.

[13] D. Kurniawan, "Pengembangan Perangkat Middleware Web Of Things (Wot) Berbasis Arsitektur Publish Subscribe Menggunakan Protokol Rest Http Skripsi," Hlm. 77, 2018.

[14] R. L. Halterman, "Learning To Program With Python," Hlm. 283, 2011.

[15] D. Agustin, "Sejarah Perkembangan Android," Hlm. 8, 2017.

[16] S. A. Sidiq Dan D. Irmawati, "Pengolahan Citra Untuk Identifikasi Telur Berdasarkan Ukuran," Vol. 1, Hlm. 6, 2016.

[17] M. Gultom, Mukhlisa Dan D. Alamsyah, "Rancang Bangun Aplikasi Pengenal Penutur Menggunakan Metode Hidden Markov Model (Hmm)," Hlm. 9, 2014.

[18] L. R. Rabiner, "A Tutorial On Hidden Markov Models And Selected Applications In Speech Recognition," Proc. Ieee, Vol. 77, No. 2, Hlm. 30, 1989.

[19] D. Ariyantini, M. Lutfi, Dan D. R. Hadiati, "Kadar Hormon Lh Basal Sebagai Prediktor Keberhasilan Stimulasi Ovarium Pada Program Bayi Tabung," J. Kesehat. Reproduksi, Vol. 5, No. 1, Hlm. 7, 2018.

[20] E. Putri, "Hubungan Pengetahuan Dengan Sikap Istri Dalam Pemilihan Kontrasepsi Alamiah Metode Ovulasi Billings (Mob)," J. Kebidanan, Vol. 7, Hlm. 6, 2017. 